\title{
Penentuan Kadar Besi selama Fase Pematangan Padi Menggunakan Spektrofotometer UV-Vis
}

\author{
Dianawati, $\mathrm{N}^{1} ;$ R. Sugiarso, R. $\mathrm{D}^{1 *)}$ \\ ${ }^{1}$ Jurusan Kimia, FMIPA Institut Teknologi Sepuluh Nopember \\ Jl. Arief Rahman Hakim, Surabaya 60111 Indonesia \\ *e-mail: djarot@chem.its.ac.id
}

\begin{abstract}
Abstrak-- Kadar besi pada padi selama fase pematangan dan pada lingkungan sekitar padi yaitu tanah maupun air ditentukan menggunakan spektrofotometer UV-Vis. Sampel padi, tanah, dan air didestruksi terlebih dahulu untuk mendapatkan ion besi. Pengukuran dilakukan dengan mereaksikan ion besi dengan pengompleks 1,10-fenantrolin sehingga terbentuk senyawa kompleks besi(II)fenantrolin. Panjang gelombang maksimum yang didapat sebesar $509 \mathrm{~nm}$ dan nilai regresi pada kurva kalibrasi $\mathrm{r}=0,9951$. Terdapat 10 variasi hari yang berada dalam fase pematangan padi (52 hari, 63 hari, 67 hari, 71 hari, 77 hari, 81 hari, 85 hari, 90 hari, 95 hari, 98 hari) di setiap sampel yang dianalisis (padi, tanah, dan air) kadar besinya. Hasil analisis menunjukkan bahwa kadar besi di dalam padi memiliki korelasi dengan kadar besi pada tanah tempat menanam padi dan tidak memiliki korelasi dengan kadar besi di dalam air yang digunakan untuk mengairi padi tersebut. Padi memiliki kadar besi tertinggi saat berumur 77 hari yaitu sebesar 0,565 mg (564,325 ppm) dan memiliki kadar besi terendah saat berumur 90 hari yaitu sebesar 0,306 mg (305,983 ppm).
\end{abstract}

Kata kunci : 1,10-Fenantrolin, gabah padi, kadar besi, spektrofotometer UV-Vis

\section{Pendahuluan}

Mineral dibagi menjadi dua yaitu mineral makro dan mineral mikro. Salah satu mineral mikro yang penting bagi tubuh adalah zat besi karena berfungsi dalam pembentukan sel darah merah dan sel oto. Zat besi yang dimaksud adalah ion-ion besi seperti ferro $\left(\mathrm{Fe}^{2+}\right)$ dan ferri $\left(\mathrm{Fe}^{3+}\right)$.

Tanaman padi memerlukan waktu 110 - 125 hari dalam proses pertumbuhannya. Proses pertumbuhan tanaman padi terbagi menjadi tiga tahap yaitu tahap vegetatif (awal pertumbuhan sampai pembentukan bakal malai), tahap reproduktif (primordia sampai pembungaan), dan tahap pematangan (pembungaan sampai gabah matang) [1]. Mineral besi tidak hanya terkandung dalam buah dan sayur saja tetapi juga terkandung dalam beras. Beras merupakan butir padi yang telah dibuang kulit luarnya (sekam). Kandungan besi pada setiap jenis butir padi berbeda - beda tergantung dengan varietas padi tersebut. Persebaran mineral besi pada butir padi juga tidak merata dimana semakin ke dalam bagian dari butir padi, maka semakin besat kandungan mineral besi tersebut [2].
Studi yang berkaitan dengan kandungan mineral pada tanaman padi telah dilakukan beberapa tahun sebelumnya. Pada tahun 2006, Siti Indrasari menganalisis kandungan mineral pada beberapa varietas padi dan kaitannya dengan kesehatan manusia. Beberapa varietas padi seperti Bengawan Solo, Limboto, IR64, Cimelati diteliti kandungan mineralnya dan hasil penelitian menunjukkan bahwa padi varietas IR64 dan Cimelati baik untuk dikonsumsi anak penderita autis sedangkan varietas Bengawan Solo baik untuk dikonsumsi wanita hamil, pekerja keras, dan penderita [2].

Pada tahun 2010, Hartati dan Suwarto menganalisis stabilitas kandungan besi dan kualitas beras pada empat varietas padi yang ditanam pada berbagai kondisi lingkungan tumbuh. Hasil penelitian menunjukkan bahwa terdapat beberapa faktor yang mempengaruhi sifat kandungan besi yaitu varietas, lingkungan, dan interaksi. Namun, beberapa faktor tersebut tidak berpengaruh pada sifat kualitas beras [3].

Penelitian mengenai keterkaitan mineral pada tanaman dengan mineral pada lingkungan tumbuh 
telah dilakukan beberapa tahun sebelumnya. Pada tahun 2006, Supriyanto melakukan penelitian untuk menentukan kadar $\mathrm{Cu}, \mathrm{Fe}$, dan $\mathrm{Zn}$ dalam tanah, tanaman teh, dan minuman teh dengan cara mendestruksi sampel dengan asam nitrat pekat hingga didapat larutan jernih. Penentuan kadar $\mathrm{Cu}$, $\mathrm{Fe}$, dan $\mathrm{Zn}$ menggunakan alat Spektrofotometer Serapan Atom. Hasil penelitian menunjukkan dua hal yaitu ketiga logam tersebut positif terdapat dalam tanah, tanaman teh maupun minuman teh dan daun pada tanaman teh mengandung logam $\mathrm{Cu}$ dan $\mathrm{Zn}$ namun tidak melebihi batas baku mutu yang berlaku [4].

Metode yang digunakan dalam penentuan kadar besi adalah spektrofotometri UV-Vis yang diawali dengan mereduksi $\mathrm{Fe}^{3+}$ menjadi $\mathrm{Fe}^{2+}$ menggunakan natrium tiosulfat lalu dikomplekskan dengan 1,10-fenantrolin sehingga terbentuklah kompleks besi berupa larutan berwarna jingga [5]. Proses optimalisasi dilakukan dengan menggunakan EDTA yang bertindak sebagai agen penopeng sehingga ion logam berat lain tidak mengganggu pengukuran sampel. Selain itu, larutan buffer asetat $\mathrm{pH}$ 4,5 yang bertujuan untuk mengatur dan menjaga $\mathrm{pH}$ lingkungan [6].

Berdasarkan hal tersebut, dilakukan sebuah penelitian yang bertujuan untuk mengetahui pola kadar besi selama fase pematangan padi dan mengetahui kaitannya dengan kadar besi pada lingkungan sekitar seperti tanah dan air.

\section{Metodologi}

\subsection{Penyiapan Larutan Stok}

Penelitian ini diawali dengan membuat berbagai larutan stok antara lain larutan $\mathrm{Fe}(\mathrm{III})$ $100 \mathrm{ppm}$ sebagai larutan besi standar, larutan $\mathrm{Na}_{2} \mathrm{~S}_{2} \mathrm{O}_{3} 100$ ppm sebagai reduktor, larutan 1,10fenantrolin 1000 ppm sebagai pengompleks, larutan EDTA 100 ppm sebagai agen penopeng, larutan buffer asetat $\mathrm{pH}$ 4,5 sebagai pengontrol suasana asam. Aseton dan aqua DM sebagai pelarut.

\subsection{Penentuan Panjang Gelombang Maksimum dan Pembuatan Kurva Kalibrasi}

Larutan standar Fe(III) direduksi menggunakan $\mathrm{Na}_{2} \mathrm{~S}_{2} \mathrm{O}_{3}$ lalu direaksikan menggunakan 1,10fenantrolin dan ditambahkan EDTA dan buffer asetat $\mathrm{pH} 4,5$. Larutan tersebut didiamkan selama 60 menit kemudian ditambahkan $5 \mathrm{~mL}$ aseton dan diencerkan hingga tanda batas.
Kurva kalibrasi dibuat dari larutan dengan enam variasi konsentrasi 0 ppm -5 ppm. Langkah kerja yang digunakan sama dengan langkah kerja pada penentuan panjang gelombang maksimum

\subsection{Pengukuran Kadar Besi pada Padi}

Padi dengan variasi umur 52 hari, 63 hari, 67 hari, 71 hari, 77 hari, 81 hari, 85 hari, 90 hari, 95 hari, dan 98 hari masing-masing dikeringkan di dalam oven selama \pm 120 menit pada suhu $110^{\circ} \mathrm{C}$ setelah itu digiling menggunakan blender lalu diayak sehingga didapatkan bubuk gabah padi. Bubuk tersebut didestruksi menggunakan $\mathrm{HCl}$ pekat selama 2 jam pada suhu $90^{\circ} \mathrm{C}$. Larutan didinginkan kemudian disaring. Filtrat dilarutkan hingga $25 \mathrm{~mL}$ dengan aqua DM. Larutan tersebut dimasukkan ke dalam labu ukur kemudian direaksikan dengan $\mathrm{Na}_{2} \mathrm{~S}_{2} \mathrm{O}_{3} 100$ ppm, 1,10fenantrolin 1000 ppm, EDTA 100 ppm, dan buffer asetat $\mathrm{pH}$ 4,5 lalu didiamkan selama 60 menit. Setelah itu ditambahkan aseton dan aqua DM hingga tanda batas lalu diukur absorbansinya menggunakan spektrofotometer UV-Vis.

\subsection{Pengukuran Kadar Besi pada Tanah}

Sampel tanah dikeringkan di dalam oven selama 24 jam pada suhu $110^{\circ} \mathrm{C}$ untuk menghilangkan kadar airnya. Setelah itu tanah diayak menggunakan ayakan 200 mesh. Tanah didestruksi menggunakan aqua regia $\left(1 \mathrm{HNO}_{3}: 3\right.$ $\mathrm{HCl}$ ) selama 2 jam pada suhu $130^{\circ} \mathrm{C}$. Larutan didinginkan kemudian difiltrasi. Filtrat dilarutkan hingga $25 \mathrm{~mL}$ dengan aqua DM. Larutan tersebut dimasukkan ke dalam labu ukur kemudian direaksikan dengan $\mathrm{Na}_{2} \mathrm{~S}_{2} \mathrm{O}_{3} 100$ ppm, 1,10fenantrolin 1000 ppm, EDTA 100 ppm, dan buffer asetat $\mathrm{pH}$ 4,5 lalu didiamkan selama 60 menit. Setelah itu ditambahkan aseton dan aqua DM hingga tanda batas lalu diukur absorbansinya menggunakan spektrofotometer UV-Vis.

\subsection{Pengukuran Kadar Besi pada Air}

Sampel air didestruksi menggunakan $\mathrm{HNO}_{3}$ pekat sekaligus dipekatkan pada suhu $130^{\circ} \mathrm{C}$ hingga volumenya menyusut lalu didinginkan. Setelah dingin, ditambahkan aqua DM lalu difiltrasi. Filtrat yang didapat volumenya ditepatkan hingga $100 \mathrm{~mL}$. Larutan tersebut dimasukkan ke dalam labu ukur kemudian direaksikan dengan $\mathrm{Na}_{2} \mathrm{~S}_{2} \mathrm{O}_{3} 100$ ppm, 1,10fenantrolin 1000 ppm, EDTA 100 ppm, dan buffer asetat $\mathrm{pH}$ 4,5 lalu didiamkan selama 60 menit. Setelah itu ditambahkan aseton dan aqua DM 
hingga tanda batas lalu diukur absorbansinya menggunakan spektrofotometer UV-Vis.

\section{Hasil dan Pembahasan}

\subsection{Penentuan Panjang Gelombang Maksimum dan Pembuatan Kurva Kalibrasi}

Panjang gelombang maksimum dapat diketahui dari absorbansi tertinggi hasil pengukuran menggunakan instrumen spektrofotometer UVVis. Rentang panjang gelombang yang digunakan adalah 400 - $600 \mathrm{~nm}$ dengan interval $1 \mathrm{~nm}$ karena senyawa kompleks besi(II)-fenantrolin memiliki warna jingga kemerahan dengan warna dasar merah dimana warna merah merupakan warna komplementer sehingga warna yang terserap pada spektrofotometer UV-Vis adalah hijau-biru yang memiliki panjang gelombang sekitar $500 \mathrm{~nm}$ dan penggunaan intreval $1 \mathrm{~nm}$ dimaksudkan agar pengukuran panjang gelombang lebih akurat. Berdasarkan Gambar 1, absorbansi tertinggi terletak panjang gelombang $509 \mathrm{~nm}$ yaitu sebesar 0,480 .

Senyawa besi(II)-fenantrolin terbentuk ion besi (ferro) yang membentuk kompleks dengan ligan 1,10-fenantrolin. Ion besi berupa $\mathrm{Fe}^{2+}$ didapat dari mereduksi $\mathrm{Fe}^{3+}$ menggunakan pereduksi natrium tiosulfat.

Kurva kalibrasi dibuat dari pengukuran absorbansi larutan standar besi(II)-fenantrolin dengan konsentrasi yang bervariasi yaitu $0 \mathrm{ppm}, 1$ ppm, 2 ppm, 3 ppm, 4 ppm, dan 5 ppm. Nilai absorbansi hasil pengukuran dibuat menjadi kurva kalibrasi seperti yang terlihat pada Gambar 2 dimana sumbu $\mathrm{x}$ adalah konsentrasi dan sumbu y adalah absorbansi. Kurva tersebut memiliki nilai regresi $\mathrm{R} 2=0,9951$ dan persamaan linier $\mathrm{y}=$ $0,1105 x+0,0031$. Persamaan linier tersebut digunakan dalam perhitungan penentuan kadar besi pada padi, tanah, dan air.

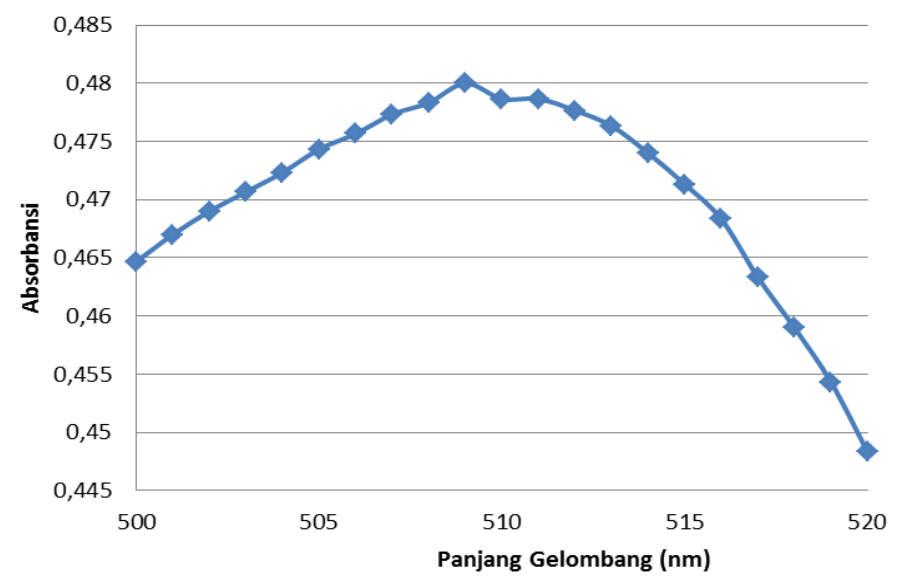

Gambar. 1. Kurva absorbansi larutan besi(II)-fenantrolin pada rentang panjang gelombang $400-600 \mathrm{~nm}$.

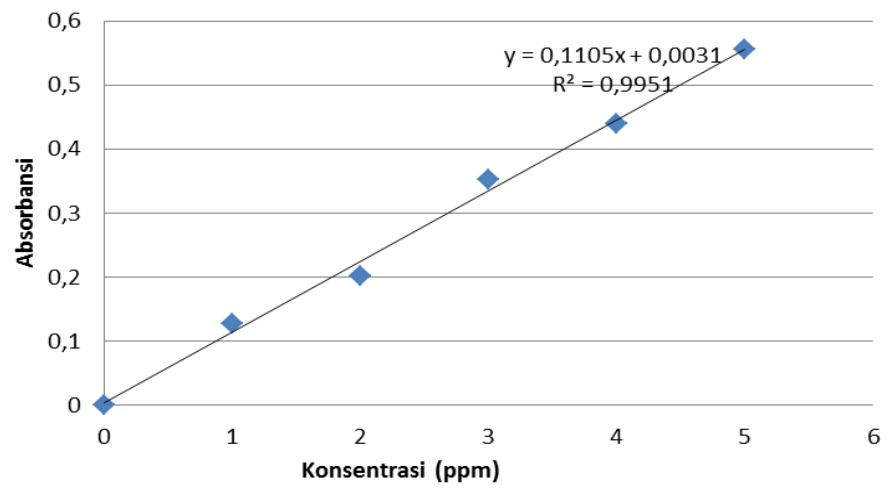

Gambar. 2. Kurva kalibrasi larutan standar besi(II)-fenantrolin 


\subsection{Kadar Besi pada Padi, Tanah dan Air}

Penentuan kadar besi dengan metode spektrofotometri UV-Vis diawali dengan melakukan preparasi dan destruksi pada sampel padi, tanah, dan air. Sampel gabah didestruksi menggunakan $\mathrm{HCl}$ pekat $37 \%$ dimana 1 gram sampel dicampur dengan beberapa $\mathrm{mL} \mathrm{HCl}$. Pada awal penambahan $\mathrm{HCl}$, larutan memiliki warna yang sesuai dengan warna bubuk gabah padi yaitu coklat krem namun pada satu jam kemudian warna larutan berubah menjadi hitam. Hal tersebut menandakan bahwa matriks sudah terlepas dari sampel dan efek wana hitam tersebut adalah warna selulosa padi yang menjadi karbon. Proses destruksi ini bertujuan untuk menghancurkan matriks sampel sehingga logam besi dapat terlepas dan berikatan dengan ion $\mathrm{Cl}$ Persamaan reaksi yang terjadi yaitu :

$$
\mathrm{Fe}^{3+}{ }_{(\mathrm{s})}+3 \mathrm{HCl}_{(\mathrm{aq})} \longrightarrow \mathrm{FeCl}_{3(\mathrm{aq})}+3 \mathrm{H}^{+}{ }_{(\mathrm{aq})}
$$

Pada sampel tanah, larutan yang digunakan adalah aqua regia. Saat awal destruksi, larutan berwarna coklat dan muncul gelembung kecil yang cukup banyak. Gelembung tersebut merupakan gas klor dan gas nitrosil klorida yang berfungsi untuk mengikat logam menjadi senyawa klorida. Berikut persaman reaksi yang terjadi :

$$
3 \mathrm{HCl}_{(\mathrm{aq})}+\mathrm{HNO}_{3(\mathrm{aq})} \longrightarrow \mathrm{Cl}_{2(\mathrm{~g})}+\mathrm{NOCl}_{(\mathrm{g})}+2 \mathrm{H}_{2} \mathrm{O}_{(\mathrm{l})}
$$

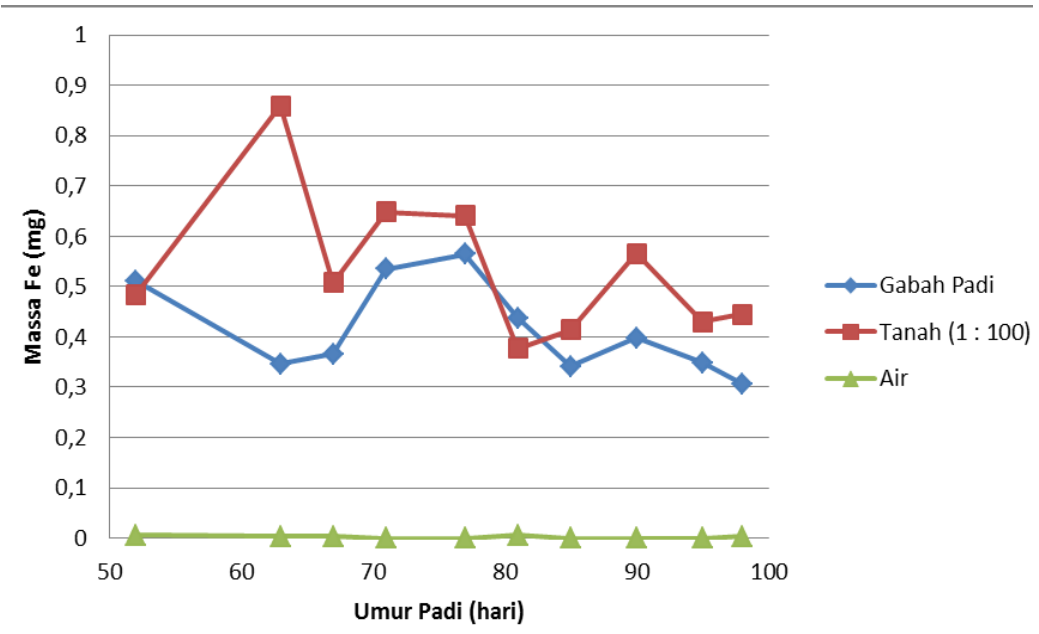

Gambar. 3. Grafik kadar besi dalam sampel terhadap umur padi

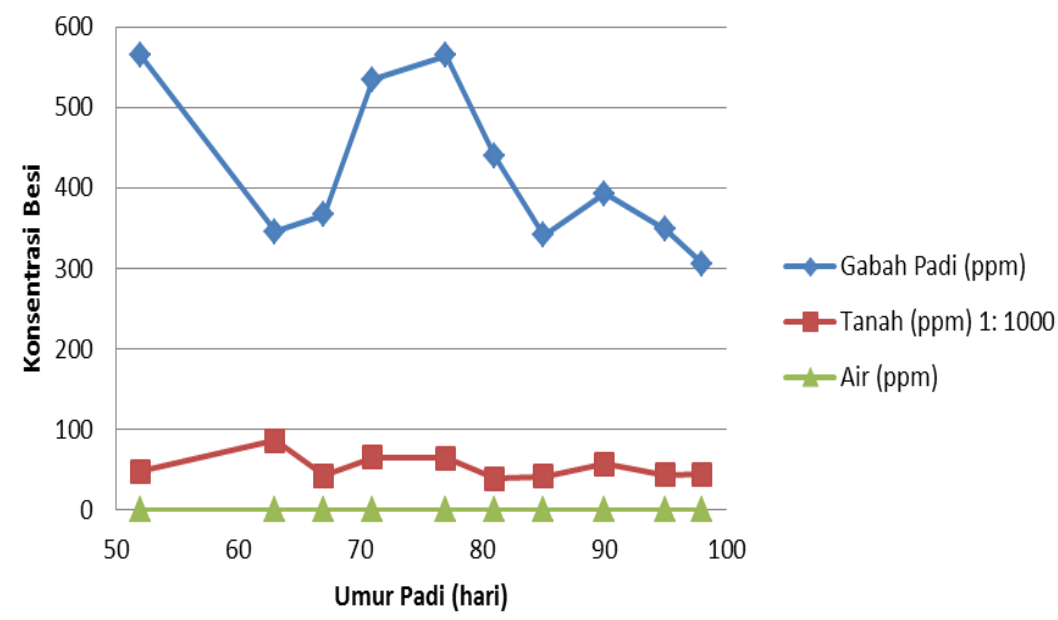

Gambar. 4. Grafik konsentrasi besi dalam sampel terhadap umur padi 
Pada akhir destruksi, larutan berwarna kuning dan terdapat endapan berwarna coklat. Endapan tersebut merupakan silika yang tidak dapat larut dengan aquaregia. Sampel air didestruksi menggunakan $\mathrm{HNO}_{3}$ pekat dengan memanaskan hingga sampel air hampir habis. Proses ini bertujuan untuk memekatkan sampel air sekaligus melepaskan ion besi yang masih terikat dalam air. Filtrat hasil destruksi dikomplekskan dengan 1,10fenantrolin. Larutan tersebut diukur absorbansinya menggunakan instrumen spektrofotometer UVVis. Nilai absorbansi yang didapat kemudian diolah melalui persamaan linier yang berasal dari kurva kalibrasi untuk mendapatkan kadar besi dalam sampel.

Berdasarkan Gambar 3. dan Gambar 4., pola kadar besi dalam sampel tanah dan padi memiliki korelasi satu sama lain, sedangkan pola kadar besi dalam air cenderung stagnan. Pola garis tanah pada tanah dan padi saat umur 52 - 67 hari memberikan pola yang saling berlawanan. Ketika kadar besi pada padi menurun, kadar besi dalam tanah justru semakin naik. Hal ini disebabkan pada rentang umur tersebut masih termasuk tahapan gabah matang susu dimana pada tahap ini kadar besi padi cenderung rendah karena cairan putih di dalam gabah masih tinggi. Sementara itu, kadar dan konsentrasi besi di tanah tergolong tinggi karena masuk dalam masa pemupukan kedua sehingga mineral di dalam tanah meningkat.

Pada umur 70 - 90 hari dimana padi memasuki tahapan gabah $1 / 2$ matang, pola antara tanah dan padi cenderung memiliki kesamaan. Kadar besi pada padi mengalami kenaikan daripada tahapan sebelumnya. Peningkatan ini disebabkan oleh menghilangnya cairan putih (pelarut) di dalam gabah sehingga zat terlarut bertambah. Sedangkan kadar besi pada tanah menurun, penyebabnya adalah pemupukan yang tidak dilakukan lagi sehingga mineral besi tidak berlimpah seperti tahapan sebelumnya.

Pada umur 90 hari hingga panen, padi memasuki tahapan gabah matang penuh dimana pada tahap ini kadar besi pada gabah lebih rendah dan polanya semakin menurun walau sempat naik di hari ke-90. Hal ini disebabkan kadar besi dalam gabah mulai terabsorb ke bagian padi yang lain dan akar padi tidak lagi menyerap mineral dalam jumlah banyak. Kenaikan ini disebabkan oleh mineral besi di tanah meningkat sehingga proses difusi besi ke dalam padi juga meningkat. Serupa dengan padi, kadar besi dalam tanah juga lebih rendah dibandingkan tahapan sebelumnya namun tanah memiliki pola yang semakin naik bahkan sempat mengalami kenaikan yang cukup signifikan di umur 90 hari. Penyebabnya adalah difusi besi dari tanah ke akar padi perlahan berkurang dan proses pengairan pada lahan tanam selama masa gabah matang dihentikan, akibatnya pelarut dalam tanah mulai berkurang perlahan sehingga zat terlarut (mineral) meninggi perlahan.

Ketiga tahapan pematangan gabah tersebut termasuk dalam fase pematangan padi. Pola yang dimiliki padi dan tanah di setiap tahapan tersebut memiliki korelasi satu sama lain sehingga tanah memiliki pengaruh terbesar terhadap keberadaan besi di dalam padi. Berdasarkan peneitian yang dilakukan oleh Indrsari, dkk kadar besi pada beras varietas Situ Bagendit hanya sebesar 3,6 ppm saja [7] sedangkan di penelitian ini diketahui bahwa gabah padi memiliki kadar besi tertinggi saat padi berumur 77 hari yaitu sebesar $0,565 \mathrm{mg}(564,325$ ppm) dan kadar besi terendah berada saat padi berumur 98 hari yaitu sebesar 0,306 mg (305,983 ppm). Kadar besi dalam air yang digunakan untuk mengairi tanaman padi selama fase pematangan, mulai dari tahapan gabah matang susu hingga gabah matang penuh cenderung sangat rendah bahkan dalam beberapa umur padi, mineral besi tidak terdeteksi. Umur tersebut antara lain 77 hari, 80 hari, 85 hari, dan 90 hari. Hal tersebut menunjukkan bahwa air yang digunkaan untuk mengairi tanaman padi tidak memiliki peranan terhadap mineral besi yang terdapat di dalam padi

\section{Kesimpulan}

Berdasarkan penelitian yang telah dilakukan, dapat disimpulkan bahwa terdapat korelasi antara kadar besi dalam padi dengan kadar besi dalam tanah yang digunakan untuk menanam padi dan tidak terdapat korelasi antara kadar besi dalam padi dengan kadar besi dalam air yang digunakan untuk mengairi padi tersebut. Padi memiliki kadar besi tertinggi saat berumur 77 hari yaitu sebesar $0,565 \mathrm{mg}(564,325 \mathrm{ppm})$ dan memiliki kadar besi terendah saat berumur 90 hari yaitu sebesar 0,306 mg (305,983 ppm).

\section{Ucapan Terimakasih}

Penulis mengucapkan terimakasih kepada Direktorat Pendidikan Tinggi, Departemen Pendidikan dan Kebudayaan Republik Indonesia yang telah memberikan dukungan finansial melalui Beasiswa Bidik Misi tahun 2011-2015 


\section{Daftar Pustaka}

[1] Makarimm K. Suhartatik, E. "Morfologi dan Fisiologi Tanaman Padi" dalam Balai Besar Penelitian Tanaman Padi, 2015, p. 295-330.

[2] Indrasari, S.D, "Kandungan Mineral Padi Varietas Unggul dan Kaitannya dengan Kesehatan", IPTEK Tanaman Pangan. Vol. 1, p. 88-99, 2006.

[3] Hartati, H., Suwarto, S., "Kandungan Nutrisi Fe dan Kualitas Beras Empat Kultivar Padi yang Ditanam pada Dua Lokasi”, Agrin. Vol 14, p. 11, 2010.

[4] Supriyanto, S., Zainul, K., "Penentuan Kadar Cu, $\mathrm{Fe}$, dan Zn dalam Tanah, Tanaman Teh, Daun Teh, dan Minuman Teh", Garendra Vol. 9, p. 2528, 2006.
[5] Puspaningtyas, "Optimasi $\mathrm{pH}$ Buffer Asetat dan Konsentrasi Larutan Pereduksi Natriu Tiosulfat dalam Penentuan Kadar Besi Secara Spektrofotometri UV-Vis", Surabaya : Kimia FMIPA ITS, bagian ke-4, 2004.

[6] Eriko, "Studi Perbandingan Penambahan Agen Penopeng Tartrat dan EDTA dalam Penentuan Kadar Besi PH 4,5 dengan Pengompleks Orto Fenantrolin Secara Spektrofotometri UV-Vis." Surabaya : Kimia FMIPA ITS , bagian keempat, 2007.

[7] Indrasar, S. D., Wibowo, P., Daradjat, A. A., "Kandungan Mineral Beras Varietas Unggul Baru" dalam dalam Balai Besar Penelitian Tanaman Padi, 2015, p. 1457 - 1472 